\title{
Decision Support System of Lecturer Selection Recommendation with Collaborative Filtering Method
}

\author{
Anton Setiawan Honggowibowo ${ }^{\mathrm{a}^{*}}$, Hero Wintolo ${ }^{\mathrm{a}}$, Yuliani Indrianingsih ${ }^{\mathrm{a}}$, Regina Maula Adiba ${ }^{\mathrm{a}}$ \\ ${ }^{a}$ Department of Informatics, Adisutjipto College Of Technology, Janti Street, Blok-R, Lanud Adisutjipto Yogyakarta \\ E-mail:"anton_s_h@yahoo.com
}

\begin{abstract}
The use of decision support systems for the selection of the best lecturers at Adisutjipto Institute of Technology (STTA) is not yet at the level of application. The average tertiary institution in selecting the best lecturers uses certain criteria, for example the criteria in teaching, research and community service. Of the three indicators of lecturer performance in Indonesia, we only use two indicators, namely research and community service. From these two indicators, we made five criteria, namely the number of presenters at the conference, the amount of community service, the number of unpublished research, the number of published research, and the number of citations of scientific articles. The selection was made by users, namely STTA Director, Vice Director for Academic Affairs, Vice Director for Financial Affairs and Community Service Research Center to 62 lecturers who were active in research, community service and publications indexed on Google Scholar. This user restriction is adjusted to the organizational structure at our university, where the five users have authority in assessing the performance of lecturers and giving awards to lecturers who are declared as the best lecturers. After Collaborative Filtering method is done to predict the final result using the rating given by the user. Based on the results of the system testing, it was concluded that the system that was built could be a solution to help select lecturers who were eligible to be given awards as the best of lecturer in the field of research and community service.
\end{abstract}

Keywords — decision support system; lecturer recommendations; collaborative filtering method.

\section{INTRODUCTION}

Decision support systems evolve along with technological developments that support computerization in decisionmaking. Almost every small and large company has a decision support system, including universities. An example is decision support systems for the selection of Lecturer in the field of research. Lecturer at the Adisutjipto College of Technology (STTA) Yogyakarta every year is always selected through selection to be awarded as an outstanding lecturer. The awarding of outstanding lecturers is expected to improve the performance and dedication of lecturer and can help to improve the value of accreditation for universities.

The use of decision support system in various fields has helped people to make various decisions, make decisions in agriculture for the diagnosis of rice plants [1], computer maintenance, [2] and spraying weeds on plants [3]. Decision support systems can also be applied to a university related to scholarship provision using TOPSIS and Weighted Product methods [4], increasing lecturer satisfaction in terms of preferences and ratings [5], and can improve library performance efficiency in a collage in providing book recommendations alternative to visitors with collaborative filtering methods [6]. So that in the article made from research using collaborative filtering methods to support of the decision of the choice of lecturers with achievements in the field research.

\section{MATERIAL AND METHOD}

\section{A. Recommendation System}

Recommendation systems are intermediary programs or representatives that intelligently compile list of information needed and match based on the wishes of users [7]. The recommendation systems aim to suggest items to users. The recommendation systems directly advise users to items that can meet their needs and desires by narrowing down information in large database [8].

\section{B. Collaborative Filtering Methods}

Collaborative filtering is the process filtering or evaluating items using the opinions of others [9]. Although the term collaborative filtering has only existed for about a decade, collaborative filtering derives from something that humans have done for centuries to share opinions with others.

Collaborative filtering is one of the algorithms used to develop the recommender system and has proven to provide 
excellent results. Rating is the most important element of this algorithm; rating is obtained from most users where the user explicitly gives an assessment of the product. The conclusions is the system gives reciprocity to the user by processing these data, as an illustration of a scale of 0 to 5 which indicates the most unpopular to the most preferred assessment according to the user's point of view, this data allows for statistical calculations which results indicate which product given a high rating by user.

TABLE I

MATRIX RATING TABLE

\begin{tabular}{|c|c|c|c|c|c|}
\hline & $\mathrm{i}_{1}$ & $\mathrm{i}_{2}$ & $\mathrm{i} 3$ & $\mathrm{i} 4$ & $\mathrm{i}_{\mathrm{n}}$ \\
\hline $\mathrm{U}_{1}$ & 1 & $\ldots$ & 3 & $\ldots$ & \\
\hline $\mathrm{U}_{2}$ & 5 & 4 & $\ldots$ & $\ldots$ & \\
\hline $\mathrm{U} 3$ & $\ldots$ & 5 & 3 & $\ldots$ & \\
\hline $\mathrm{U} 4$ & $\ldots$ & 4 & $\ldots$ & $\ldots$ & \\
\hline $\mathrm{U}_{\mathrm{n}}$ & & & & & \\
\hline
\end{tabular}

Collaborative filtering uses a database obtained from the user. There are two main components in this data in order to make predictions for the recommender system, namely the user and the item, which in this case is a criterion. Both from matrix ratings in the form of $\mathrm{m}$ user $\{\mathrm{u} 1, \mathrm{u} 2, \mathrm{u} 3 \ldots \mathrm{um}\}$ and $\mathrm{a}$ list of $n$ item $\{i 1, i 2, i 3 \ldots$ in $\}$. Where each user is gives an assessment of the item in the form of a rating on a scale of 1 to 5. Iul denotes this rating. Not all users give ratings to each product due to various factors, this cause the number of missing values that result in data sparsely. User rating matrix items can be described with the table1.

There are two main approaches in the collaborative filtering method, namely:

1) User-based collaborative filtering: This algorithm works based on the assumption that each user is part of group that has similarities with other users. The basis of the recommendation with this algorithm is that the recommendations produced the arranged based on items that are liked by each user. Recommended items are the result of recommendations according to what other users like. Based on items that have been chosen by the closest neighbor of a user, items that are likely to be chosen by the user in the future are predicted [10]. Algorithms that are often used include the Pearson Correlation Coefficient (PCC) algorithm, the Vector Space Similarity (VSS) algorithm.

2) Item-based collaborative filtering: This algorithm works to find relationships between items based on the rating table to form a recommendation for an item to the user. To produce recommendations, first a correlation model between items is needed with the aim of knowing the relationship between items according to the rating obtained. Correlation models can be done offline using various other techniques, such as association rule, classifications or clustering. To make a recommendation system using the item-based collaborative filtering method, there are three steps that must be done, namely:

- Determine the user item-rating matrix.

- Calculate Similarity with the formula adjusted cosine similarity.

$$
\operatorname{sim}(i, j)=\frac{\sum_{u \in U}\left(R_{u, i}-\bar{R}_{i}\right)\left(R_{u, j}-\bar{R}_{j}\right)}{\sqrt{\sum_{u \in U}\left(R_{u, i}-\bar{R}_{u}\right)^{2}} \sqrt{\sum_{u \in U}\left(R_{u, j}-\bar{R}_{u}\right)^{2}}}
$$

Description:

$\operatorname{sim}(i, j)=$ Similarity value between item $\mathrm{i}$ and item $\mathrm{j}$

$u \in U=$ User set that evaluates item $\mathrm{i}$ and item $\mathrm{j}$

$R_{u, i} \quad=\mathrm{u}$ User rating $\mathrm{u}$ on items $\mathrm{i}$

$\bar{R}_{i} \quad=$ Average value of rating item $\mathrm{i}$

$R_{u, j} \quad=\mathrm{u}$ User rating on item $\mathrm{j}$

$\bar{R}_{j} \quad=$ Average value of rating item $\mathrm{j}$

$\bar{R}_{u} \quad=$ Average rating for user $\mathrm{u}$

Calculate rating predictions with Weight Sum:

$$
\boldsymbol{P}_{u, i}=\frac{\sum_{i \in l}(S(i, j) \times R(u, j))}{\sum_{i \in l}|S(i, j)|}
$$

Description:

$P(u, i)=$ Prediction of user rating for item $\mathrm{i}$

$i \in I \quad=$ Set of item similar to item $\mathrm{i}$

$S(i, j)=$ Value of Similarity between item $\mathrm{i}$ on item $\mathrm{j}$

$R_{u, j} \quad=\mathrm{u}$ user rating on item $\mathrm{j}$

\section{Decision Support Systems}

Decision support system (DSS) is defined as a system intended to support managerial decision making in certain situation. Decision support systems are intended to be a tool for decision makers to expand their capabilities, but not to replace their judgments [11]. Application of decision support systems can consist of several subsystems, including data management, model management, user interface and knowledge based management [12].

\section{RESULTS AND DISCUSSION}

\section{A. Rating}

In recommendation system with the collaborative filtering method, the role of rating is very important to determine the final item worthy to be recommended. In calculating the DSS recommendations of lecturers with achievements in the field of research, the rating obtained by each lecturer depends on the number of values possessed by each criterion. Rating will be done automatically based on the weight given to each user who gives an assessment.

The first thing to be done before giving a rating is to determine the criteria; In this case, five criteria have been determined, namely:

$\mathrm{P} 1=$ Number of presenter

$\mathrm{P} 2$ = Number of community services

P3 = Number of unpublished research

P4 = Number of publish research

P5 = Number of citations

TABLE II

RATING TABLE

\begin{tabular}{|c|c|c|}
\hline No. & Column Name & Type of Data \\
\hline 1. & 5 & Very Good \\
\hline 2. & 4 & Good \\
\hline 3. & 3 & Enough \\
\hline 4. & 2 & Less \\
\hline 5. & 1 & Very Less \\
\hline
\end{tabular}


After determining the criteria, the second phase is determining the suitability rating of each alternative criteria.
Rating is given from values 1 to 5 , details of the rating table can be seen Table II.

TABLE III

RATING WEIGHTING TABLE

\begin{tabular}{|c|c|c|c|c|c|c|c|c|c|c|c|c|}
\hline \multirow[t]{3}{*}{ No } & \multirow[t]{3}{*}{ User } & \multirow{3}{*}{$\begin{array}{c}\text { Criteria } \\
\text { Code }\end{array}$} & \multicolumn{10}{|c|}{ Rating } \\
\hline & & & \multicolumn{2}{|c|}{1} & \multicolumn{2}{|c|}{2} & \multicolumn{2}{|c|}{3} & \multicolumn{2}{|c|}{4} & \multicolumn{2}{|c|}{5} \\
\hline & & & BB & BA & BB & BA & BB & BA & BB & BA & BB & BA \\
\hline \multirow[t]{5}{*}{1.} & \multirow[t]{5}{*}{ Director STTA } & P1 & 0 & 0 & 1 & 2 & 3 & 4 & 5 & 6 & 7 & $>7$ \\
\hline & & P2 & 0 & 1 & 2 & 3 & 4 & 5 & 6 & 8 & 9 & $>9$ \\
\hline & & P3 & 0 & 1 & 2 & 3 & 4 & 5 & 6 & 8 & 9 & $>9$ \\
\hline & & $\mathrm{P} 4$ & 0 & 1 & 2 & 3 & 4 & 5 & 6 & 8 & 9 & $>9$ \\
\hline & & P5 & 0 & 5 & 6 & 10 & 11 & 20 & 21 & 30 & 31 & $>31$ \\
\hline \multirow[t]{5}{*}{2.} & \multirow{5}{*}{$\begin{array}{l}\text { Vice Director for } \\
\text { Academic Affair }\end{array}$} & $\mathrm{P} 1$ & 0 & 0 & 1 & 1 & 2 & 3 & 4 & 4 & 5 & $>5$ \\
\hline & & $\mathrm{P} 2$ & 0 & 1 & 2 & 3 & 4 & 5 & 6 & 8 & 9 & $>9$ \\
\hline & & P3 & 0 & 1 & 2 & 2 & 3 & 5 & 6 & 7 & 8 & $>8$ \\
\hline & & $\mathrm{P} 4$ & 0 & 0 & 1 & 2 & 3 & 4 & 5 & 5 & 6 & $>6$ \\
\hline & & P5 & 0 & 5 & 6 & 15 & 16 & 25 & 26 & 40 & 41 & $>41$ \\
\hline \multirow[t]{5}{*}{3.} & \multirow{5}{*}{$\begin{array}{l}\text { Vice Director for } \\
\text { Financial Affair }\end{array}$} & $\mathrm{P} 1$ & 0 & 0 & 1 & 1 & 2 & 3 & 4 & 5 & 6 & $>6$ \\
\hline & & $\mathrm{P} 2$ & 0 & 2 & 3 & 4 & 5 & 6 & 7 & 7 & 8 & $>8$ \\
\hline & & P3 & 0 & 1 & 2 & 3 & 4 & 5 & 6 & 7 & 8 & $>8$ \\
\hline & & $\mathrm{P} 4$ & 0 & 1 & 2 & 4 & 5 & 6 & 7 & 8 & 9 & $>9$ \\
\hline & & P5 & 0 & 10 & 11 & 20 & 21 & 30 & 31 & 40 & 41 & $>41$ \\
\hline \multirow[t]{5}{*}{4.} & \multirow{5}{*}{$\begin{array}{l}\text { Community } \\
\text { Service Research } \\
\text { Center }\end{array}$} & P1 & 0 & 1 & 2 & 2 & 3 & 4 & 5 & 5 & 6 & $>6$ \\
\hline & & P2 & 0 & 1 & 2 & 3 & 4 & 5 & 6 & 7 & 8 & $>8$ \\
\hline & & P3 & 0 & 2 & 3 & 5 & 6 & 7 & 8 & 9 & 10 & $>10$ \\
\hline & & P4 & 0 & 1 & 2 & 4 & 5 & 5 & 6 & 7 & 8 & $>9$ \\
\hline & & P5 & 0 & 5 & 6 & 10 & 11 & 20 & 21 & 30 & 31 & $>31$ \\
\hline
\end{tabular}

Description: $\mathrm{BB}=$ Lower limit value $\mathrm{BA}=$ Upper limit value

The third is weighting each rating based on the value of each criterion. Users who have the authority to perform system calculations carry out weighting. Users who have authority include the Director STTA, Vice Director for Academic Affair, Vice Director for Financial Affair and Community Service Research Center. Weighting will vary according to the rating weight given by each user. The detailed table of weights can be seen in Table III.

Table III shows the range of values for each criterion. In the rating column, we can see the weights for the 1-5 rating. The rating is given based on the weight of the predetermined value. For example, the details of the weight of the Director STTA give weight to the criteria P1 to P5 with the detailed rating criteria.

$\mathrm{P} 1$ is the amount as a presenter. For rating 1has a range of lower limit 0 and upper limit 0 (range $0-0$ ). For rating 2 has a range of lower bound 1 and upper limit 2 (range 1-2). For rating 3 has a range of lower limit 3 and upper limit 4 (range $3-4)$. For rating 4 has a range of lower limit 5 and upper limit 6 (range 5-6). For rating 5 has a lower limit range of 7 and an upper limit range of $<7$. For example, suppose that the lecturer has been a presenter 2 times than the P1 rating that the lecturer gets from the Director STTA is 2, because the rating of 2 for $\mathrm{P} 1$ has a range of 1-2.

$\mathrm{P} 2$ is the number of community service. For rating 1 has a range of lower limits 0 and upper limit 1 (range 0-1). For rating 2 has a range of lower limit 2 and upper limit 3 (range $2-3$ ). The rating 3 has a lower limit range of 4 and upper limit of 5 (range 4-5). For rating 4 has a range of lower limit 6 and upper limit 8 (range 6-8). For rating 5 has a lower limit range of 9 and upper limit range of $<9$. For example, in 1 year the lecturer has done community service 4 times, then the P2 rating that the lecturer gets from the Director STTA is 3 , because rating 3 for $\mathrm{P} 2$ has a range of 4-5.

$\mathrm{P} 3$ is the number of unpublished research. For rating 1 has a range of lower limit 0 and upper limit 1 (range 0-1).For rating 2 has a range of lower limit 2 and upper limit 3 (range 2-3). The rating 3 has a lower limit range of 4 and upper limit of 5 (range 4-5). For rating 4 has a range of lower limit 6 and upper limit 8 (range 6-8). For rating 5 has a lower limit range of 9 and an upper limit range of $<9$. For example, suppose that in 1 year, there were 3 unpublished research, then P3 rating that the lecturer got from the Director STTA was 2, because the rating 2 for $\mathrm{P} 3$ had a range of 2-3.

$\mathrm{P} 4$ is the number of published research. For rating 1 has a range of lower limit 0 and upper limit 1 (range 0-1). For rating 2 has a range of lower limit 2 and upper limit 3 (range $2-3)$. For rating 3 has a lower limit range of 4 and upper limit of 5 (range 4-5). For rating 4 has a range of lower limit 6 and upper limit 8 (range 6-8). For rating 5 has a lower limit range of 9 and an upper limit range of $<9$. For example, suppose that in 1 year there are 6 published research, the P4 rating that the lecturer gets from the Director STTA is 4, because the 4 rating for $\mathrm{P} 4$ has a range of (6-8).

P5 is citation. For rating 1 has a range of lower limit 0 and an upper limit 5 (range 0-5). For rating 2 has a range of lower limit 6 and an upper limit 10 (range 6-10). The rating 3 has a lower limit range of 11 and an upper limit of 20 (range 11-20). For rating 4 has a range of lower limit 21 and an upper limit of 30 (range 21-30). For rating has a range of lower limit 31 and an upper limit range is 130 . For example, suppose that the number of citations from lecturers research 
is 22 then the P5 rating that the lecturer gets from the Director STTA is 4 , because the 4 to P5 rating has a range of $21-30$.

After weighting, the fourth is to convert the number of values the lecturer has into a rating according to the weight entered. Details of the value of each criterion P1 to P5 that is owned by the lecturer can be seen in Table IV. The values in Table $\mathrm{V}$ will be converted into ratings according to the weight given by each user.

TABLE IV

Detail Value Amount Table

\begin{tabular}{|c|l|c|c|c|c|c|}
\hline \multirow{2}{*}{ No. } & \multirow{2}{*}{ Lecturer Name } & \multicolumn{5}{|c|}{ Criteria } \\
\cline { 3 - 7 } & & P1 & P2 & P3 & P4 & P5 \\
\hline 1. & Hero W. & 0 & 0 & 0 & 4 & 14 \\
\hline 2. & Anton S. H. & 0 & 0 & 0 & 6 & 72 \\
\hline 3. & Mardiana I. & 0 & 0 & 0 & 0 & 4 \\
\hline 4. & Astika A. & 0 & 0 & 0 & 6 & 0 \\
\hline 5. & Haruno S. & 0 & 0 & 0 & 6 & 4 \\
\hline
\end{tabular}

From the detailed number of values in Table 4.3 shows the Hero W. Lecturer has a number of criteria values $\mathrm{P} 1=0$, criteria $\mathrm{P} 2=0, \mathrm{P} 3=0, \mathrm{P} 4=4, \mathrm{P} 5=14$. For the number of second lecturers and so on according with Table IV.

The results of conversion of values to rating can be seen in Table V. This table shows the results of the conversion of each lecturer from the criteria P1 to P5 criteria. To get a rating, the numbers in Table IV are compared with the weights in Table III. Each lecturer has four different conversion results; this is because four users who have different rating weights carry out the assessment.

TABLE V

CONVERSION RESULT TABLE

\begin{tabular}{|c|c|c|c|c|c|c|c|}
\hline \multirow[t]{2}{*}{ No } & \multirow[t]{2}{*}{ User } & \multirow{2}{*}{$\begin{array}{l}\text { Lecturer } \\
\text { name }\end{array}$} & \multicolumn{5}{|c|}{ Criteria } \\
\hline & & & P1 & $\mathbf{P 2}$ & P3 & P4 & P5 \\
\hline \multirow[t]{5}{*}{1.} & \multirow{5}{*}{$\begin{array}{l}\text { Director } \\
\text { STTA }\end{array}$} & Hero W. & 1 & 1 & 1 & 3 & 3 \\
\hline & & Anton S.H & 1 & 1 & 1 & 4 & 5 \\
\hline & & Mardiana I & 1 & 1 & 1 & 1 & 1 \\
\hline & & Astika A. & 1 & 1 & 1 & 4 & 1 \\
\hline & & Haruno S. & 1 & 1 & 1 & 4 & 1 \\
\hline \multirow[t]{5}{*}{2.} & \multirow{5}{*}{$\begin{array}{l}\text { Vice } \\
\text { Director for } \\
\text { Academic } \\
\text { Affair }\end{array}$} & Hero W. & 1 & 1 & 1 & 3 & 2 \\
\hline & & Anton S. H. & 1 & 1 & 1 & 5 & 5 \\
\hline & & Mardiana I & 1 & 1 & 1 & 1 & 1 \\
\hline & & Astika A. & 1 & 1 & 1 & 5 & 1 \\
\hline & & Haruno S. & 1 & 1 & 1 & 5 & 1 \\
\hline \multirow[t]{5}{*}{3.} & \multirow{5}{*}{$\begin{array}{l}\text { Vice } \\
\text { Director for } \\
\text { Financial } \\
\text { Affair }\end{array}$} & Hero W. & 1 & 1 & 1 & 2 & 2 \\
\hline & & Anton S. H. & 1 & 1 & 1 & 3 & 5 \\
\hline & & Mardiana I & 1 & 1 & 1 & 1 & 1 \\
\hline & & Astika A. & 1 & 1 & 1 & 3 & 1 \\
\hline & & Haruno S. & 1 & 1 & 1 & 3 & 1 \\
\hline \multirow[t]{5}{*}{4.} & \multirow{5}{*}{$\begin{array}{l}\text { Community } \\
\text { Service } \\
\text { Research } \\
\text { Center }\end{array}$} & Hero W. & 1 & 1 & 1 & 3 & 3 \\
\hline & & Anton S.H & 1 & 1 & 1 & 4 & 5 \\
\hline & & Mardiana I. & 1 & 1 & 1 & 1 & 1 \\
\hline & & Astika A. & 1 & 1 & 1 & 4 & 1 \\
\hline & & Haruno S. & 1 & 1 & 1 & 4 & 1 \\
\hline
\end{tabular}

The results of the conversion of criteria based on the weight given by the Director STTA for Hero W. Lecturer are as follows:

- The number of criteria value $\mathrm{P} 1=0$, then the criteria rating $\mathrm{P} 1=1$

- The number of criteria value $\mathrm{P} 2=0$, then the criteria rating $\mathrm{P} 2=1$

- The number of criteria value $\mathrm{P} 3=0$, then the criteria rating $\mathrm{P} 3=1$

- The number of criteria value $\mathrm{P} 4=4$, then the criteria rating $\mathrm{P} 3=$

- The number of criteria value P5 $=14$, then the criteria rating $\mathrm{P} 5=3$.

For the conversion results, the criteria for the second lecturer and so on are in accordance with table V. The criteria value weights can be seen in Table III. The number of criteria values P1 to P5 can be seen in Table IV. The fifth step is to find the average rating of each lecturer, which then becomes the final rating. Each lecturer will have four average values obtained from four users, namely Director STTA, Vice Director for Academic Affair, Vice Director for Financial Affair, and Community Service Research Center. The calculation of the average rating of each lecturer obtained from the Director STTA is as follows:

- Average lecturer rating of Hero Wintolo

$$
=\frac{1+1+1+3+3}{5}=1.8
$$

- Average lecturer rating of Anton Setiawan H.:

$$
=\frac{1+1+1+4+5}{5}=2.4
$$

- Average lecturer rating of Mardiana Irawati:

$$
=\frac{1+1+1+1+1}{5}=1
$$

- Average lecturer rating of Astika Ayuningtyas:

$$
=\frac{1+1+1+4+1}{5}=1.6
$$

- Average lecturer rating of Haruno Sajati:

$$
=\frac{1+1+1+3+3}{5}=1.6
$$

For the final rating details of all users can be seen in Table VI.

TABLE VI

FINAL RATING DETAILS

\begin{tabular}{|c|l|c|c|c|c|}
\hline \multirow{2}{*}{ No } & $\begin{array}{c}\text { Lecturer } \\
\text { Name }\end{array}$ & $\begin{array}{c}\text { Director } \\
\text { STTA }\end{array}$ & $\begin{array}{c}\text { Vice } \\
\text { Director } \\
\text { for } \\
\text { Academic } \\
\text { Affair }\end{array}$ & $\begin{array}{c}\text { Vice } \\
\text { Director } \\
\text { for } \\
\text { Financial } \\
\text { Affair }\end{array}$ & $\begin{array}{c}\text { Community } \\
\text { Service } \\
\text { Research } \\
\text { Center }\end{array}$ \\
\hline 1. & Hero W. & 1.8 & 1.6 & 1.4 & 1.6 \\
\hline 2. & $\begin{array}{l}\text { Anton } \\
\text { S.H. }\end{array}$ & 2.4 & 2.6 & 2.2 & 2.4 \\
\hline 3. & $\begin{array}{l}\text { Mardian } \\
\text { a I. }\end{array}$ & 1 & 1 & 1 & 1 \\
\hline 4. & $\begin{array}{l}\text { Astika } \\
\text { A. }\end{array}$ & 1.6 & 1.8 & 1.4 & 1.6 \\
\hline 5. & $\begin{array}{l}\text { Haruno } \\
\text { S. }\end{array}$ & 1.6 & 1.8 & 1.4 & 1.6 \\
\hline \multicolumn{2}{|l|}{ Average } & 1.68 & 1.76 & 1.48 & 1.64 \\
\hline
\end{tabular}

The sixth step is to find similarity between lecturers with the following calculations: 


$$
\operatorname{sim}(i, j)=\frac{\sum_{u \in U}\left(R_{u, i}-\bar{R}_{i}\right)\left(R_{u, j}-\bar{R}_{j}\right)}{\sqrt{\sum_{u \in U}\left(R_{u, i}-\bar{R}_{u}\right)^{2}} \sqrt{\sum_{u \in U}\left(R_{u, j}-\bar{R}_{u}\right)^{2}}}
$$

Based on the calculation of similarity above, a similarity value is chosen which has the highest value, namely 1 . Then after obtaining similarity values, the seventh step is to find predictions using the similarity value that has been determined with the following details:

- Prediction Director STTA

$$
\begin{aligned}
& \text { Pred } A=\frac{1 \cdot 1.2}{|1|}=1.2 \\
& \text { Pred } B=\frac{1 \cdot 1.8}{|1|}=1.8 \\
& \text { Pred } C=\frac{1 \cdot 2.8}{|1|}=2.8 \\
& \text { Pred } D=\frac{1 \cdot 2.8}{|1|}=2.8 \\
& \text { Pred } \mathrm{E}=\frac{1 \cdot 3.2}{|1|}=3.2
\end{aligned}
$$

- Prediction Vice Director for Academic Affair

$$
\begin{aligned}
& \text { Pred } \mathrm{A}=\frac{1 \cdot 1.4}{|1|}=1.4 \\
& \text { Pred } \mathrm{B}=\frac{1 \cdot 2.0}{|1|}=2.0 \\
& \text { Pred } \mathrm{C}=\frac{1 \cdot 2.8}{|1|}=2.8 \\
& \text { Pred } \mathrm{D}=\frac{1 \cdot 2.8}{|1|}=2.8 \\
& \text { Pred } \mathrm{E}=\frac{1 \cdot 3.4}{|1|}=3.4
\end{aligned}
$$

- Prediction Vice Director for Financial Affair

$$
\begin{aligned}
& \text { Pred } A=\frac{1 \cdot 1.0}{|1|}=1.0 \\
& \text { Pred } B=\frac{1 \cdot 1.4}{|1|}=1.4 \\
& \text { Pred } C=\frac{1 \cdot 2.6}{|1|}=2.6 \\
& \text { Pred D }=\frac{1 \cdot 2.4}{|1|}=2.4 \\
& \text { Pred } \mathrm{E}=\frac{1 \cdot 3.0}{|1|}=3.0
\end{aligned}
$$

- Prediction Community Service Research Center

$$
\begin{aligned}
& \text { Pred } A=\frac{1 \cdot 1.2}{|1|}=1.2 \\
& \text { Pred } B=\frac{1 \cdot 1 \cdot 6}{|1|}=1.6 \\
& \text { Pred } C=\frac{1 \cdot 2.4}{|1|}=2.4 \\
& \text { Pred } D=\frac{1 \cdot 2.6}{|1|}=2.6 \\
& \text { Pred } E=\frac{1 \cdot 3.0}{|1|}=3.0
\end{aligned}
$$

After the prediction calculation is obtained, then the last one is sorting the results of the calculation of the predictions of the five lecturers from each user, namely the Director STTA, Vice Director for Academic Affair, Vice Director for Financial Affair, and Community Service Research Center. Calculations are sorted from the highest number to the lowest number. The results of the prediction sequence are the final result of the recommendation.

\section{B. Comparison of Manual Calculation and System Calculation}

The results of the manual calculation of the DSS recommendation of the outstanding lecturers in the research were determined from the final value of the prediction calculation. Details of the final results of the manual calculation of DSS recommendation can be seen in Table VII.

TABLE VII

Details of Manual Calculation Result

\begin{tabular}{|c|l|l|l|l|}
\hline \multirow{2}{*}{ No. } & \multicolumn{4}{|c|}{ Final rating } \\
\cline { 2 - 5 } & \multicolumn{1}{|c|}{$\begin{array}{c}\text { Director } \\
\text { STTA } \\
\text { for Academic } \\
\text { Affair }\end{array}$} & $\begin{array}{l}\text { Vice } \\
\text { Director for } \\
\text { Financial } \\
\text { Affair }\end{array}$ & $\begin{array}{l}\text { Community } \\
\text { Service } \\
\text { Research } \\
\text { Center }\end{array}$ \\
\hline 1. & $\begin{array}{l}\text { Anton S. H. } \\
(2.4)\end{array}$ & $\begin{array}{l}\text { Anton S. H. } \\
(2.6)\end{array}$ & $\begin{array}{l}\text { Anton S. H. } \\
(2.2)\end{array}$ & $\begin{array}{l}\text { Anton S. H. } \\
(2.4)\end{array}$ \\
\hline 2. & Hero W. (1.8) & Haruno S. (1.8) & $\begin{array}{l}\text { Haruno S. } \\
(1.4)\end{array}$ & $\begin{array}{l}\text { Haruno S. } \\
(1.6)\end{array}$ \\
\hline 3. & Haruno S. (1.6) & Astika A. (1.8) & $\begin{array}{l}\text { Hero W. } \\
(1.4)\end{array}$ & $\begin{array}{l}\text { Hero W. } \\
(1.6)\end{array}$ \\
\hline 4. & Astika A. (1.6) & Hero W. (1.6) & $\begin{array}{l}\text { Astika A. } \\
(1.4)\end{array}$ & $\begin{array}{l}\text { Astika A. } \\
(1.6)\end{array}$ \\
\hline 5. & Mardiana I. (1) & Mardiana I. (1) & $\begin{array}{l}\text { Mardiana I. } \\
(1)\end{array}$ & $\begin{array}{l}\text { Mardiana I. } \\
(1)\end{array}$ \\
\hline
\end{tabular}

\section{CONCLUSIONS}

From the results of testing on Decision Support Systems Recommendations of achieving lecturers in the field of research with collaborative filtering methods can be taken some conclusions. The first is based on sample of data that has been tested that is as many as 5 lecturer indicate that the results of application calculations are the same as the manual calculation results. The second conclusion is that this system can be used as a solution to provide recommendations for lecturers who are eligible to be awarded as outstanding lecturers in the field of research.

\section{REFERENCES}

[1] A. S. Honggowibowo, "Sistem Pakar Diagnosa Penyakit Tanaman Padi Berbasis Web Dengan Forward Dan Backward Chaining,"TELKOMNIKA (Telecommunication Computing Electronics and Control), vol. 7, no. 3, p. 187, Dec. 2009.

[2] F. Sukmana and F. Rozi, "Decision Support System On Computer Maintenance Management SystemUsing Association Rule and Fisher Exact Test One Side P-Value," TELKOMNIKA (Telecommunication Computing Electronics and Control), vol. 15, no. 4, p. 1841, Dec. 2017.

[3] R. M. Sampurno, K. Boro Seminar, and Y. Suharnoto, "Weed Control Decision Support System Based on Precision Agriculture Approach," TELKOMNIKA (Telecommunication Computing Electronics and Control), vol. 12, no. 2, p. 475, Jun. 2014.

[4] S. 'Uyun and I. Riadi, "A Fuzzy Topsis Multiple-Attribute Decision Making for Scholarship Selection," TELKOMNIKA (Telecommunication Computing Electronics and Control), vol. 9, no. 1, p. 37, Apr. 2011.

[5] H. Babaei, J. Karimpour, and A. Hadidi, "Applying Hybrid Fuzzy Multi-Criteria Decision-Making Approach to Find the Best Ranking for the Soft Constraint Weights of Lecturers in UCTP," International Journal of Fuzzy Systems, vol. 20, no. 1, pp. 62-77, Feb. 2017.

[6] P. R. Hasibuan, A. S. Honggowibowo, and H. Wintolo, "Sistem Pakar Rekomendasi Peminjaman Buku Di Perpustakaan Sekolah Tinggi Teknologi Adisutjipto Yogyakarta Dengan Metode Penyaringan Kolaboratif," Compiler, vol. 1, no. 1, May 2012.

[7] N. Mittal, R. Nayak, M. C. Govil, and K. C. Jain, "Recommender System Framework Using Clustering and Collaborative Filtering," 2010 3rd International Conference on Emerging Trends in Engineering and Technology, Nov. 2010. 
[8] S. Parvatikar and B. Joshi, "Online book recommendation system by using collaborative filtering and association mining," 2015 IEEE International Conference on Computational Intelligence and Computing Research (ICCIC), Dec. 2015

[9] J. B. Schafer, D. Frankowski, J. Herlocker, and S. Sen, "Collaborative Filtering Recommender Systems," Lecture Notes in Computer Science, pp. 291-324.
[10] M.S. Babu \& B.R.S. Kumar, An implementation of the user-based collaborative filtering algorithm, International Journal of Computer Science and Information Technologies 2,3, 2011: 1283-86.

[11] E. Turban, J.E. Aronson, \& T.P. Liang, Decision Support Systems and Intelligent Systems (Sistem Pendukung Keputusan dan Sistem Cerdas) edisi ketujuh jilid 1, Yogjakarta: Andi Offset, 2005.

[12] Kusrini, Concepts and Applications of Decision Support Systems, Andi Offset, 2007. 